\title{
Financial Deepening and Deposit Mobilization of Commercial Banks in Nigeria: A Time Variant Model
}

\author{
Azu-Nwangolo ${ }^{1} \&$ Blessing Ogechi ${ }^{1}$ \\ ${ }^{1}$ Department of Banking and Finance, Rivers State University, Port Harcourt, Nigeria \\ Correspondence: Azu-Nwangolo, Department of Banking and Finance, Rivers State University, Port Harcourt, \\ Nigeria
}

Received: May 20, 2018

Accepted: May 28, 2018

Online Published: June 13, 2018

\begin{abstract}
The purpose of this study was to examine the effect of financial deepening on customer deposit of Nigerian commercial banks. Time series data was sourced from Central Bank of Nigeria Statistical Bulletin, from 1981-2017. Percentage of total customers' deposit to total assets was used as dependent variables while percentage of narrow money supply, broad money supply, money market development, money outside the bank and private sector credit to gross domestic product was used as independent variables. Multiple regression with ordinary least square properties of cointegration, augment Dickey Fuller unit root test, Granger causality test and vector error correction model was used to examine the relationship between the dependent and the independent variables. The regression result found that narrow money supply and money market development have negative effect on total customer's deposit of commercial banks while private sector credit, broad money supply and money outside the bank have positive effect on customer's deposit of commercial banks in Nigeria. The unit root test shows that the variables are stationary at first difference; the cointegration test validates the existence of long run relationship while the causality test found no causal relationship. The study concludes that financial deepening has significant impact on total customer deposit. We recommend that policies should be deepened to enhance the performance of the Nigeria financial market.
\end{abstract}

Keywords: Financial Deepening, Commercial Banks, Deposit Mobilization, Broad Money Supply, Narrow Money Supply.

\section{Introduction}

Commercial banks are the institutional transmission mechanism for monetary policy. They facilitate the realization of the monetary policy goals and enhance the functionality of the payment system in Nigeria. Interest rates are the most influential auto-pilot instrument used to achieve set monetary policy and macroeconomic goals (Ngerebo-a and Lucky, 2016). The demand side of the financial intermediation function represents the deposit mobilization function of a typical financial institution. Financing function, according to finance theory, is the function of the firm geared toward the sourcing and/or raising of funds from alternative sources in such a cost-effective and time-efficient manner as to enable the firm to achieve its objectives. Deposit Mobilization is one of the primary functions of a commercial bank. Deposits mobilized by banks play a key role not only as an important source of funds for banks but also as instrument for promoting saving and banking habit among the people. Deposits are essential raw material for the banking industry. Commercial banks are expected to make efforts in both the rural and urban areas for mobilizing savings in the form of their deposits which are beneficial to them and the country as well. Commercial banks deposits can be short term, long term or medium term. It can also be government or private sector deposit. In Nigeria, significant proportion of commercial banks deposit is from government and agencies.

Financial sector deepening enable the financial intermediaries perform their functions of mobilizing, pooling and channeling domestic savings into productive capital more effectively thereby contributing to economic growth of a country (Ndege, 2012). In addition to mobilizing savings and improving capital allocation (Boyd and Prescott, 1986), financial deepening reduces the extent and significance of information asymmetries (Stiglitz and Greenwald, 2003) and allows for risk transformation and monitoring (Diamond 1984). Financial sector deepening has been seen 
to lead to access of long term capital which deemed crucial for economic development as evidenced by the positive relationship between long term capital and economic growth (Klapper \& Panos, 2007). Financial deepening generally entails an increased ratio of money supply to gross domestic product (Nnanna and Dogo, 1998; and Nzotta, 2004).

Conceptually, defines financial deepening refers to the improvement or increase in the pool of financial services that are tailored to all the levels in the society (Shaw and McKinnon, 1973). It also refers to the increase in the ratio of money supply to Gross Domestic Products or price index which ultimately postulates that the more liquid money is available in the economy, the more opportunities exist in that economy for continued and sustainable growth. It basically supports the view that development in financial sectors leads to development of the economy as a whole. Increase financial deepening in the emerging financial market affect banking efficiency and productivity through competition and ultimately a more efficient capital allocation which increases the productivity of investment, and mobilizes savings into investment projects, which normally are passed on by the banking sector (Merton and Bodie, 1995). Financial deepening also increases the marginal productivity of capital through the intermediation function of well-informed financial institutions (King and Levine, 1993a; Beck, Levine, and Loayza, 2000).On the other hand, more efficient and profitable banks may increase the degree of financial deepening by increasing competition, improving their services, increasing their network penetration, enhancing transaction processes, and providing consumers with more financial products. The effect of financial deepening has well been examined in literature, however significant proportion of the literature focused on financial deepening and economic growth (Chotareas et al., 2011, Sindani, 2013, Ocanda, 2014). There is no known study on financial deepening and deposit mobilization in commercial banks most especially developing countries of Africa and Nigeria in particular. Therefore, this study examined the effect of financial deepening and deposit mobilization in Nigeria.

2. Literature Review

2.1 Concept of Financial Deepening

The concept of financial deepening varies among scholars. Financial deepening has been defined as an increase in the supply of financial assets in the economy (Hamilton and Godwin, 2013). It includes the aggregate or wide range of financial assets that are available in the economy. Financial deepening also implies the ability of financial institutions to effectively mobilize savings for investments. The growth of domestic savings provides the real structure for the creation of diversified financial claims. Financial deepening generally entails an increased ratio of money supply to Gross Domestic Product (Christian, 2013). Financial deepening/development thus involve the establishment and expansion of institutions, instruments and growth process. Osinsanwo (2013) describes financial deepening as increased financial services geared to all levels of the society. Onyemachi (2012) defined financial deepening as an effort aimed at developing the financial system that is evident in increased financial instrument/assets in the financial markets-money and capital markets, leading to the expansion of the real sector of the economy. Obviously, it is the effort of developing countries to achieve growth through financial intermediation.

2.2 Theoretical Foundation

Mckinnon/Shaw theory of suggested that any distortion and limitation on the banking sector, such as interest rate controls, reserve and liquidity requirement, and government rationing of available credit to so-called priority sectors, inhibit financial development mainly by depressing the interest rate McKmnon (1973), Shaw, (1973), Galbis, (1997) ,Mathiesun (1980), Capannelli (2009). The deficiency in the amount of savings due to such repressive measures thwarts economic development through the perverse effects on the volume and the quantity of investment. Thus, the main argument of McKinnon and Shaw is that financial repression has a detrimental effect on financial development, hence on bank performance. Mckinnon and Shaw believes that financial repression needs to end in emerging countries and advocate for financial liberalization. They opined that countries need to develop its financial sphere to increase its real growth. Financial repression implies a series of constraints: the necessity for banks to have no remunerated reserves in the central banks, too low interest rates for savers etc. that are so strong that financial sphere cannot be developed. For this economists are of the opinion that financial repression leads to domestic agents to prefer having unproductive assets or no monetary assets rather than depositing assets in the bank. Based on this reason there are not enough funds to be lent in the economy, which create an obstacle for investment and thus for growth.

The supply leading hypothesis suggests that financial deepening fuels growth. The existence and development of the financial markets brings about a higher level of savings and investment and enhance the efficiency of capital accumulation. The contention of this hypothesis is that, a well-functioning financial institutions can promote overall economic efficiency, create and expand capital accumulation, transfer resources from traditional (non-growth) sectors to the modern growth inducing sectors and also promote a competent entrepreneur response in these modern sectors of the economy. Early economists have strongly supported the view of finance led caused relationship 
between finance and economic growth. These authors are of the opinion that causality proceeds from financial to economic development, it is only at a later stage that financial development leads on to growth.

Demand-Following Hypothesis was of the opinion that economic activity propels banks to finance enterprises. Thus, where enterprises lead, finance follows. This hypothesis view is that the development of the financial markets is merely a lagged response to economic growth. This implies that any early efforts to develop financial markets might lead to a waste of resources which could be allocated to more useful purposes in the early stages of growth. As the economy advances, this triggers an increase demand for more financial services and thus leads to greater financial development. Some research work postulate that economic growth is a casual factor for financial development. According to them, as the real sector grows, the increasing demand for financial services stimulates the financial sector.

2.3 Empirical Review

Beck and Levine (2002) employ a cross-country panel data to test the relationship between financial structure, industry growth, and new establishment formation. They find that an efficient legal system and financial development are both strong determinants of industry growth, new establishment formation and efficient capital allocation. Fisman and Love (2003) test how financial deepening affects productivity growth. They found that in the long-run more financially developed countries allocate a higher share of resources towards sectors that rely primarily on external finance. These industries which depend on external financing are most likely to invest in R\&D and technology, and access to increased credit may stimulate greater productivity growth. Bossone\& Lee (2004) examined the relationship between production efficiency and financial system size. The study was carried out on 875 banks in 75 countries. The data covered 1995-1997. Absolute size of the financial system was measured as a constructed comprehensive indicator for open economies by summing domestic credit, domestic deposits, foreign assets, and foreign liabilities of the banking system, expressed in billions of U.S. dollars. Relative size of the financial system was measured using financial depth. The study found that financial depth was positively related to scale efficiency. This suggests that financial deepening has a positive influence on bank productivity.

Ndebbio (2004) examined the effect of financial deepening on economic growth and development. The study used growth rate of per capita (real/nominal) money balances (GPRMB/GPMB) and degree of financial intermediation/development (M2/GDP) as proxies for financial deepening. Data was collected for 34 countries in Sub-Sahara Africa (SSA) from 1980-1989. The study found that financial deepening had apositive effect on per capita growth of output. This implies that financial deepening influenced economic growth and development of SSA countries.

Hartmann et al. (2007) show that financial deepening in Eastern European countries has led to faster capital reallocation; they conclude that deeper credit markets enhance capital reallocation by contributing to an increase in economic productivity growth. Lower TFP has been explained in developing countries by misallocation of resources across productive units. Thus, the presence of financial frictions increases the misallocation of resources (G.E. Chortareas et al, 2008). Contrastingly, as the financial system develops, information and transaction costs associated with capital reallocation decrease while TFP increases (Hsieh and Klenow, 2007; Restuccia and Rogerson, 2007). Odhiambo (2009a) examined the impact of interest rate reforms on financial deepening and economic growth in Kenya. The study used financial depth as a measure of financial deepening and it was measured using the ratio of broad money stock to gross domestic product (M2/GDP). Annual time series data from 1968 to 2004 was utilised. Using co-integration and error-correction models, the study found a positive impact of interest rate reforms on financial deepening in Kenya. The study also revealed that financial deepening Granger cause economic growth in Kenya. Interest rate liberation therefore moderated the effect of financial deepening on economic growth in Kenya. Odhiambo (2009b) examined the inter-temporal causal relationship between financial deepening and poverty reduction in Zambia. Annual data from 1969 to 2006 was used in the study. The study used three proxies of financial deepening namely broad money supply ratio (M2/GDP), domestic credit to the private sector as a ratio of gross domestic product (DCP/GDP) and domestic money bank assets (DMBA). Poverty reduction was measured using private per capita consumption. The study found that financial sector development leads to poverty reduction. This shows that financial deepening leads to poverty reduction.

Chortareas, et al., (2011) examined the possible effects of financial deepening on bank productivity changes as well as the possibility of a two-way causality in Latin America. The authors obtained bank productivity estimates using the non-parametric Malmquist methodology. The data was obtained for 9 Latin American countries for the period 2000-2006 with a total of 973 observations. The dependent variable was total factor productivity while financial deepening was measured using the ratio of credit to the private sector to GDP. The study found strong evidence of causality from financial deepening to bank productivity and also evidence of reverse causality. The results suggested that a virtuous circle between financial deepening and financial institutions' productivity may exist. Sanchez, Hassan, \& Bartkus (2013) investigated the determinants of productivity across Latin American banking industries. 
DEA was used to estimate the Malmquist Index as a proxy for efficiency (productivity) for the banks for the period 1996-2007. One of the independent variables was a vector for financial development: domestic credit to the private sector provided by banks as a percent of GDP, the total value of stocks traded as a percent of GDP, the total assets of the threelargest banks divided by the total assets in the country, interest rate spread (lending rate minusdeposit rate), and the number of banks in the country. Proxies for financial development showed mixed results. For instance, concentration, measured as total assets of the three biggest banks over the country's total bank assets, was negatively related to efficiency. Also, economic efficiency and allocative efficiency were negatively related to both credit provided by banks to the private sector and stocks traded as percentage of the GDP.

Kenyoru (2013) examined the effect of financial innovations on financial sector development (financial deepening). Financial deepening was measured as number of depositors with commercial banks and other institutions per 1000 adults. Financial innovations were measured as number of mobile money transactions, number of agency banking transactions, and value of m-banking transactions. The data was collected for the period 2007-2012. The results showed that mobile money Transactions had a negative effect on financial deepening while value of m-banking transactions had a positive effect on financial deepening. The effect of agency transactions was not shown. However, none of the effects were significant suggesting no significant effect of financial innovations on financial deepening. Sindani (2013) examined the impact of financial sector deepening on economic development in Kenya. The study used 44 commercial banks using data from 2007 to 2011 . Financial deepening was measured using ATM network and deposit accounts. The results showed a negative effect of ATM network and positive effect of deposit accounts on economic development, measured as the GDP. This reveals that the consequences of financial deepening on economic development are mixed depending on the measure used. Ochanda (2014) examined the effect of financial deepening on growth of small and medium-sized enterprises (SMEs) in Kenya with a specific focus on Nairobi County. Survey data was collected from 100 SMEs. Financial deepening was measured using financial innovations and credit access. The results showed that both credit access and financial innovations had positive effects on growth of SMEs. These suggest that financial deepening positively influence growth of SMEs in Kenya.

Ayadi et al (2013) explore the relationship between financial sector development and economic growth across the Mediterranean, using data covering the period of 1985 - 2009. The study found that credit to the private sector and bank deposits are negatively associated with growth, which in the authors' opinion, portend deficiencies in credit allocation in the region and suggest weak financial regulation and supervision. Abou-Zeinab (2013) reviews patterns of bank credit allocation and economic growth in Sweden over the period of 1736 - 2012, and found that banking system exhibits tendency of reallocating bank credit toward service and trade activities for onward economic growth in the country. The results of Granger causality test and estimated regression models conducted by Akpansung and Babalola (2012) indicated that private sector credit impacts positively on economic growth in Nigeria over the period 1970- 2008. The study established that lending rate impedes growth, and recommends the need for more financial market development that favours more credit to the private sector to stimulate economic growth. Bhusal (2012) investigates the impact of policy reforms on financial development and economic growth in Nepal, using exogenous break test, and time series data ranging from 1965 to 2009. The study could not establish positive relationship between bank domestic credit and economic growth. The study suggests that the finding might be due to some problems which inhibit the banking sector in the country, such as inadequate expansion of commercial banks and their branches in the rural non-monetized sector, non-performing loans that discouraged credit allocation, among others.

Were et al (2012) investigate the impact of access to bank credit on the economic performance of key economic sectors using sectoral panel data for Kenya. The study found a positive relationship between bank credit access and sectoral gross domestic product measured as real value added. Also, they found that provision of private sector credit to key economic sectors of the economy holds great potential to promoting sectoral economic growth. The study emphasizes on financial deepening and intermediation, as of utmost importance in providing real sector with credit facilities. Fafchamps and Schundeln (2011) investigate whether firm expansion is affected by local financial development in Moroccan manufacturing enterprises from 1998 to 2003, using regression analysis test. The study found that local bank availability is robustly associated with faster growth for small and medium size firms in sectors with growth opportunities.

Avinash and Mitchell-Ryan (2009) investigated the impact of the sectoral distribution of commercial bank credit on economic growth and development in Trinidad and Tobago. The study employs Vector Error Correction Model to ascertain the relationship that exists between credit and investment. The study found that credit and growth tends to demonstrate a demand following relationship, while further analysis revealed a 'supply leading relationship between credit and growth within key sectors of the non-oil economy. Nazmi (2005) studied the impact of deregulation and financial deepening on the real sector, using general equilibrium model to analyze data from four (4) Latin America 
countries, for the period covering 1960 - 1995. The study found that deregulation and a more developed banking sector prompt firms to increase the capital intensity of production, mostly, portends rapid economic growth.

Toby and Peterside (2014) analyzed the role of banks in financing the agriculture and manufacturing sectors in Nigeria for the period of 1981-2010. The study found that increment in availability of credit to those sectors, which are inclusive in the real sector of the economy, has potential of increasing Gross Domestic Products (GDP). Thereby, the study recommended mandatory credit allocation to real sector of the economy. Abubakar and Gani (2013) in their study on impact of banking sector development on economic growth, using Vector Error Correction Modelling (VECM) with data covering the period of 1970 - 2010, found a negative relationship between credit to the private sector and economic growth, due to unfavourable feat of credit going into real sector. The study emphasized on financial deepening towards real sector.

Imoughele et al (2013) carried out a study on the impact of commercial bank credit accessibility and sectoral output performance in Nigeria economy for period of 1986 to 2010, using OLS techniques. The study found that cumulative supply and demand for credit in the previous period has direct and significant impact on the growth of agriculture, manufacturing and the service sector output. The study attributed the development to the importance of credit facility as an input in the production process and persistent inflow to the manufacturing, agriculture and services sectors. The study further encourage continuous credit accessibility in a deregulated financial market economy as it has the capacity to induce the national real sector outputs, which would subsequently result to economic growth and development. Obilor (2013) empirically investigated the impact of commercial banks' credit to agricultural sector under the Agricultural Credit Guarantee Scheme Fund in Nigeria. The study found that joint action of commercial banks credit to the agricultural sector, agricultural credit guarantee loan by purpose, government financial allocation to agricultural sector and agricultural products prices are significant factors that can influence agricultural production in the country. The study recommends that farmers should be encouraged to be applying for loans from participating banks to enhance agricultural activities and productivity.

Ikenna (2012) studied the long and short run impact of financial deregulation and the possibility of a credit crunch in the real sector, using Autoregressive Distributed Lag (ARDL), and time series data ranging from 1970 - 2009. The study found that deregulating the Nigerian financial system had an adverse effect on the credit allocation to the real sector in the long run and in the short run. The study suggested mandatory credit allocation even in the long run as of utmost necessity as it had started with the latest banking reform. Omankhanlen (2012) examined the financial sector reforms and its effect on the Nigerian economy from 1980 - 2008, using OLS method. Financial intermediation was found to be necessary condition for stimulating investment, raising productive capacity and fostering economic growth. Fadare (2010) investigated the effect of banking sector reforms on economic growth in Nigeria over the period of 1999 - 2009, using OLS regression technique. The study found that interest rate margins, parallel market premiums, total banking sector credit to the private sector, inflation rate, size of banking sector, capital and cash reserve ratios account for a very high proportion of the variation in economic growth in the country. Tomola et al (2010) investigated the effect of bank lending and economic growth on the manufacturing output in Nigeria, using time series data covering the period of 36 years. They also employed co-integration and vector error correction model (VECM) techniques to analyse the data. It was found that manufacturing capacity utilization and bank lending rates significantly affect manufacturing output in Nigeria. The study recommended that policies that would foster investment friendly lending and borrowing by the financial institutions should be put in place by the appropriate authority.

Nwanyanwu (2009) investigated the role of bank credit in economic growth of Nigeria. The study found that bank credit did not exhibit positive relationship towards economic growth. The study claimed that this was due to apathy exhibited in lending to the private sector for productive purposes. The study recommended that the regulating body such as Central Bank of Nigeria $(\mathrm{CBN})$ should adopt a direct credit control that will be beneficial to the real sector of the economy, which is the latest reform in the banking sector, where there is mandatory credit allocation to critical sectors of the economy. Nabar (2011) assesses how interest rate affects household savings in Chinese 31 provincial level administrative units between 1996 and 2009. A strong positive correlation between household savings and interest rates was established; suggesting that Chinese save to meet a number of needs e.g. retirement consumption and durables purchases. As such high savings rates enable them to meet their target savings. Mohan (2012) examined deposit mobilization by cooperative banks in India. The study showed that cooperative banks should rely on individual's depositors as well as cooperative societies. Their efforts should be oriented towards the mobilization of more savings and current accounts deposits through continuous publicity, effective marketing management and providing good service to the clients. Das \& Das (2002) discuss the relationship deposit interest rates and the interest amount. They observed that the method of calculating the interest amount can substantially affect the interest paid. Depositors should take into consideration the interest rate computation over and above the 
quoted nominal rates. Since $89 \%$ of the customers are depositors, a high degree of transparency is needed in regard to effective rates offered to customers.

Laurenceson (2004) drawing on a panel data of 101 countries between 1994 and 2001 examined the relationship between bank franchise values and deposit mobilization. Results showed a negative relationship between franchise value and a decrease in deposits; suggesting that increased competition leads to improvements in service quality which tempts households to raise their holdings of savings deposits. In this regard it can be argued that high interest rate on deposits leads to higher deposits (ceteris paribus). Oluitan (2009) is of the opinion that policy makers should focus less on measures leading to increase in bank lending and concentrate more on legal, regulatory and policy reforms that boost the functioning of markets and banks. Muhsin\& Eric (2000) in their study on Turkey concluded that economic growth lead to financial sector development. However, the proponents of supply-leading hypothesis are of the belief that bank lending is a veritable tool for attainment of economic growth and development.

Anthony (2012) investigated the determinants of bank savings in Nigeria as well as examined the impact of bank savings and bank credits on Nigeria's economic growth from 1970-2006. The study adopted two impact models; Distributed Lag-Error Correction Model (DL-ECM) and Distributed Model, the empirical results showed a positive influence of values of GDP per capita (PCY), Financial Deepening (FSD), Interest Rate Spread (IRS) and negative influence of Real Interest Rate (RIR) and Inflation Rate (INFR) on the size of private domestic savings. Also a positive relationship exists between the lagged values of total private savings, private sector credit, public sector credit, interest rate spread, exchange rates and economic growth. The study therefore recommend, among others, that government's effort should be geared towards improving per capita income by reducing the unemployment rate in the country in a bid to accelerate growth through enhanced savings.

Jelilov (2015) in his study on the impact of interest rate and economic growth in Nigeria from posited that the Nigerian economy faced numerous challenges which impacted on the overall economic activity and has witnessed crises with devastating consequences on the world commodity prices as a result of global economic. This subsequently created structural imbalances occasioned by the collapse of oil prices which adversely affected the Nation's revenue. Study examined the impact of interest rate on economic growth in Nigeria from 1990 to 2013. The result found that the interest rate has a slight impact on growth; however the growth can be improved by lower the interest rate which will increase the investment. As a result of study was found out that Nigerian authorities should set interest rate policies that will boost the economic growth. Therefore, proper measure should be taken in order to have a more rapid economic growth. Akabom-Ita, (2012) examined the impact of interest rate on net assets of multinational companies in Nigeria from 1995 - 2010. The regression analysis showed that an increase in interest rate results in reduction in net assets. Okoye and Richard (2013) examined the impact of bank lending rate on the performance of Nigerian Deposit Money Banks between 2000 and 2010. The study specifically determined the effects of lending rate and monetary policy rate on the performance of Nigerian Deposit Money Banks and analyzed how bank lending rate policy affects the performance of Nigerian deposit money banks. It utilized secondary data econometrics in a regression, where time-series and quantitative design were combined and estimated. The result confirmed that the lending rate and monetary policy rate has significant and positive effects on the performance of Nigerian deposit money banks. The implication of these is that lending rate and monetary policy rate are true parameter of measuring bank performance. They therefore recommend that government should adopt policies that will help Nigerian deposit money banks to improve on their performance and that there is need to strengthen bank lending rate policy through effective and efficient regulation and supervisory framework.

Enyioko (2012) also looked at the Impact of Interest Rate Policy on Performance of Deposit Money Banks in Nigerian. The study observed that the current credit crisis and the transatlantic mortgage financial turmoil have questioned the effectiveness of bank consolidation programme as a remedy for financial stability and monetary policy in correcting the defects in the financial sector for sustainable development. Many banks consolidation had taken place in Europe, America and Asia in the last two decades without any solutions in sight to bank failures and crisis. The study attempts to examine the performances of banks and macro-economic performance in Nigeria based on the interest rate policies of the banks. The study analyses published audited accounts of twenty (20) out of twenty-five (25) banks that emerged from the consolidation exercise and data from the Central Banks of Nigeria (CBN). It denoted year 2004 as the pre-consolidation and 2005 and 2006 as post-consolidation periods for our analysis. The study noticed that the interest rate policies have not improved the overall performances of banks significantly and also have contributed marginally to the growth of the economy for sustainable development.

3. Research Methodology

This study adopted ex-facto research design to explore the relationship between financial deepening indicators and customers deposit mobilization in Nigeria commercial banks. The data employed in this study are secondary data. The data were extracted from relevant publications of the Central Bank of Nigeria (CBN) such as: CBN Statistical Bulletin, annual published financial statement of the selected banks and National Bureau of Statistics (NBS). 
Secondary data was employed as it is useful to the researcher in answering research questions about social issues and significantly aid advancement of the social sciences. The choice of secondary data was made as it is faster, reduces time wastages in data gathering, it is non-reactive, often available for re-analysis, it also provides a broad background and readily improves one's learning curve. Secondary data is neither better nor worse than the primary data; it is simply different. The source of the data is not as important as its quality and its relevance for particular purposes.

For this purpose, the theoretical model of Lucky and Uzah, (2016) was adapted by taking into account the influence of financial deepening variables on deposit mobilization in Nigeria commercial banks. The model explains the theoretical link between monetary policy transmission mechanism and domestic real investment in Nigeria. Due to the assumed linearity of the model specified; Ordinary Least Squares (OLS) estimation method was employed to obtain the intercept and coefficients of the model. The estimates were used to determine the relationship between financial deepening and deposit mobilization. Also the estimates and relevant statistics were used to evaluate the models for consistency or otherwise with expectations, statistical significance and explanatory power.

\subsection{Model Specification}

Econometric models used in this research work include the Regression Analysis and the Vector Auto-regression (VAR) Model. The choice of multiple regression models is based on the use of more than single independent variables in a regression model. The study adopts modified model of Owuor (2013) on the relationship between real interest rate and financial deepening in Kenya. Components of financial deepening have implication on commercial bank liquidity management. In this study, increase in liquidity management is conceptualized as the function of variation in financial deepening. We have therefore, chosen a combination of deductive and inductive analytical framework to achieve the objective of the study.

$\mathrm{CD}=\mathrm{f}(\mathrm{FD})$

The focus of this study is to evaluate the effect of financial deepening on customer deposit of commercial banks. In other words, changes in customer deposit depend on changes in components of financial deepening.

$\mathrm{CD}=\mathrm{f}(\mathrm{FD})$

$\mathrm{H} 0: \alpha=0$

$\mathrm{H} 1: \alpha \neq 0$

At $5 \%$ level of significance

Note: $\mathrm{HO}$ is the null hypothesis that the parameter of financial deepening is not significant and $\mathrm{Ha}$ is the alternative hypothesis that the financial deepening parameter influences changes in commercial bank customer deposit.

3.2 Variables in the Model

This research adopts the econometric approach of Vector Auto-regression (VAR) Model of the form;

$\mathrm{U}(\mathrm{VAR})=(\mathrm{LIQM})$

Where:

FD= LIQM,

We assumed that the economy is described by a system of equations where:

$\mathrm{TCD}=(\mathrm{M} 1 / \mathrm{GDP}, \mathrm{M} 2 / \mathrm{GDP}, \mathrm{PSC} / \mathrm{GDP}, \mathrm{MOB} / \mathrm{M} 2, \mathrm{MMD} / \mathrm{M} 2)$

Where

TCD/TA $=$ Total customer deposit mobilized by commercial banks to Total assets

M1/GDP = Narrow Money Supply to Gross Domestic Product

M2/GDP = Broad Money Supply to Gross Domestic Product

PSC/GDP = Private sector credit to Gross Domestic Product

MOB/GDP = Money Outside the Bank to Gross Domestic Product

$\mathrm{MMD} / \mathrm{GDP}=$ Money market development to Gross Domestic Product

3.3 Unit Root Test

Given the non-stationarity characteristics of most macroeconomic variables, testing the properties of these variables has become relevant to avoid spuriousness of empirical result. In this view this study commenced its econometric analysis by conducting the stationary properties of the variables using the Augmented Dickey-Fuller tests. The ADF test is based on estimating the equation below:

$\Delta \mathrm{Yt}=\beta 1+\beta 2 \mathrm{t}+\delta \mathrm{Yt}-1+\Delta \mathrm{Yt}-1+\mu \mathrm{t}$

Where,

$\mu$ is pure white noise error; $\mathrm{n}$ is the maximum lag length on dependent variable to ensure that $\mu \mathrm{t}$ is the stationary random error.

$\Delta \mathrm{Yt}-1=(\mathrm{Yt}-1-\mathrm{Yt}-2), \Delta \mathrm{Yt}-2=(\mathrm{Yt}-2-\mathrm{Yt}-3)$ and so on. 
Note; that the number of lagged difference terms to include is often determined empirically, the idea is to include enough terms so that the error term is serially uncorrelated. And the ADF unit root test null hypothesis $\delta=0$ is rejected if the $\mathrm{t}-$ statistics associated with the estimated coefficient exceeds the critical values of the test.

3.4 Cointegration Test

Given that the empirical model specified in the study is a multivariate model, the Engle - Granger (1987) cointegration test is inappropriate for testing co-integration among the variables. This is because the Engel - Granger approach is based on the assumption that there exist only one co-integrating vector that connect the variables and since our model is multivariate there is the possibility of having more than one cointegration vector. In the light of the above weakness the Johansen cointegration test was applied. Johansen and Juselius (1990) test proposes the use of two likelihood ratio tests namely, the trace test and the maximum eigen-values test. The trace statistic for the null hypothesis of cointegrating relations is computed as follows:

Гtrace $(\mathrm{rlk})=-\mathrm{T}(1-\lambda \mathrm{t})$

Where $\mathrm{k}$ is the number of endogenous variables, for $\mathrm{r}=0,1, \ldots, \mathrm{k}-1$.

Maximum eigen-value static tests the null hypothesis of $r$ cointegrating relation against $r+1$ cointegrating relations and is computed as follows:

$\Gamma \max (r \mid r+1)=-\operatorname{Tlog}(1-\lambda r+1)$

$=\Gamma \operatorname{trace}(\mathrm{r} \mid \mathrm{k})-\Gamma \operatorname{trace}(\mathrm{r}+1 \mid \mathrm{k})$

for $\mathrm{r}=0,1, \ldots, \mathrm{k}-1$.

The Error Correction Mechanism (ECM) from the cointegrating equations, is obtain by including the lagged errorcorrection term obtain from residual of the long run static model. This process helps in capturing the long-run information that might have been probably lost during the differencing. For the result to be consistent with theory, the coefficient of the error term should be negative and range between zero and one in absolute term. The errorcorrection term to be estimated represents the short-run to long-run adjustment equilibrium trends. It is a measure of the speed of adjustment of the short run relation to unexpected shocks. It is measured as the effects of residual from the long run model.

\subsection{Granger Causality Test}

The Granger causality approach measures the precedence and information provided by a variable $(\mathrm{X})$ in explaining the current value of another variable (Y). In other words, the lagged values of $\mathrm{X}$ are statistically significant. If otherwise, then one concludes that $\mathrm{X}$ does not granger-cause $\mathrm{Y}$. To determine whether causality runs in other direction, from $\mathrm{X}$ to $\mathrm{Y}$, one simply repeats the experiment, but with $\mathrm{X}$ and $\mathrm{Y}$ interchanged. The null hypothesis $\mathbf{H}_{\mathbf{0}}$ tested is that $\mathrm{X}$ does not granger-cause $\mathrm{Y}$ and $\mathrm{Y}$ does not granger cause $\mathrm{X}$. The test involves estimating the following pairs of regressions:

$\mathrm{CDt}=\alpha 1 \mathrm{FDt}-I+\alpha 2 \mathrm{CDt}-i+u 1 t$

$\mathrm{CDt}=\beta 1 \mathrm{CD}-i+\beta 2 \mathrm{FDt}-i+u 2 t$

Where: $\alpha_{1}, \alpha_{2}, \beta_{1}$ and $\beta_{2}$ are parameter to be estimated.

From equation (1) a certain component of FD is said to granger cause a selected CD if the coefficient of the lagged values of the selected FD is significantly different from zero. Feedback relationship occurs, when FD granger cause $\mathrm{CD}$ and LIQM granger cause FD. The hypothesis that either FD granger causes a given CD, if supported by the data, should imply that the null hypothesis should be rejected.

3.6 Priori Expectation

A rise in the ratio of FD (M2/GDP) was expected to have a positive effect on deposit mobilization, such that as the ratio of money supply rises, deposit mobilization increases since the ability of banks to mobilize deposit mobilization depends on the availability of stock of money held by these banks for transactions. Symbolically, the expectations were represented, thus: $\beta 0>0, \beta 1>0, \beta 2>0, \beta 3>0, \beta 4>0, \beta 5>0$.

4. Analysis and Discussion of Findings

Table1. Short run Dynamic Results on the Effect of Financial Deepening on Customers' Deposit of Commercial Banks

\begin{tabular}{lllll}
\hline VARIABLE & COEFFICIENT & STD ERR. & T-STATISTICS & PROB. \\
\hline PSC_GDP & 0.168555 & 0.964893 & 0.174687 & 0.8625 \\
\hline MOB_GDP & 2.995304 & 2.839526 & 1.054861 & 0.3002 \\
\hline MMD_GDP & -0.012153 & 0.330659 & -0.036755 & 0.9709 \\
\hline M2_GDP & 1.622905 & 1.916366 & 0.846866 & 0.4040 \\
\hline M1_GDP & -3.782777 & 2.598420 & -1.455799 & 0.1562 \\
\hline C & 48.13160 & 8.259770 & 5.827232 & 0.0000 \\
\hline R2 & 0.699451 & & & \\
\hline
\end{tabular}




\begin{tabular}{ll}
\hline ADJ. R2 & 0.555816 \\
\hline F-STATISTICS & 4.640516 \\
\hline F-PROB & 0.000640 \\
\hline Durbin-Watson stat & 0.936894 \\
\hline
\end{tabular}

Source: Extracts from E-view

The estimated regression model reveals the impact of the independent variables on the dependent variables. The regression summary shows that the independent variables can explain 69.9 and $55.5 \%$ variation on the dependent variable (Adjusted $\mathrm{R}^{2}$ ) while the remaining $30.1 \%$ and $45.5 \%$ can be explained by exogenous variables not captured in the regression model. The F-statistics and the F-probability coefficient show that the model is significant; this led to the acceptance of alternate hypothesis. The Durbin Watson statistics of 0.936 is less than 1.00 but greater than 0.5 which shows the presence of serial auto correlation. The $\beta$ coefficient of the variable shows all the independent variables have positive relationship with the dependent variable except money market development. The presence of serial autocorrelation enables us to test for stationarity of the variables using the Augmented Dickey Fuller statistics.

Table 2. Unit Root Test Summary Results at Level

\begin{tabular}{ccccccc}
\hline VARIABLE & ADF & \multicolumn{3}{c}{ MACKINNON } & PROB. & ORDER OF INTR. \\
\cline { 2 - 5 } & STATISTICS & $\mathbf{1 \%}$ & $\mathbf{5 \%}$ & $\mathbf{1 0 \%}$ & & \\
\hline TCD/TA & -4.711927 & -3.661661 & -2.960411 & -2.619160 & 0.0007 & $1(0)$ \\
\hline M1_GDP & -2.316793 & -3.639407 & -2.951125 & -2.614300 & 0.1727 & $1(0)$ \\
\hline M2_GDP & -2.078209 & -3.639407 & -2.951125 & -2.614300 & 0.2542 & $1(0)$ \\
\hline MMD_GDP & -1.543145 & -3.639407 & -2.951125 & -2.614300 & 0.5000 & $1(0)$ \\
\hline MOB_GDP & -1.602823 & -3.639407 & -2.951125 & -2.614300 & 0.4703 & $1(0)$ \\
\hline PSC_GDP & -1.902770 & -3.639407 & -2.951125 & -2.614300 & 0.3272 & $1(0)$ \\
\hline \multicolumn{7}{c}{ Unit Root Test Summary Results at First Difference } \\
\hline TCD/TA & -5.597566 & -3.679322 & -2.967767 & -2.622989 & 0.0001 & $1(1)$ \\
\hline M1_GDP & -5.215673 & -3.646342 & -2.954021 & -2.615817 & 0.0002 & $1(1)$ \\
\hline M2_GDP & -5.471094 & -3.646342 & -2.954021 & -2.615817 & 0.0001 & $1(1)$ \\
\hline MMD_GDP & -5.169993 & -3.646342 & -2.954021 & -2.615817 & 0.0002 & $1(1)$ \\
\hline MOB_GDP & -5.688768 & -3.646342 & -2.954021 & -2.615817 & 0.0000 & $1(1)$ \\
\hline PSC_GDP & -5.833811 & -3.653730 & -2.957110 & -2.617434 & 0.0000 & $1(1)$ \\
\hline
\end{tabular}

Source: Extracts from E-view

The stationarity test as shown in the Table above proved that the variable are not stationary at level as the ADF statistics is less than the Mackinnon critical values of $1 \%, 5 \%$ and $10 \%$ and the probability coefficient is greater than 0.05 critical value. Therefore we conclude that the variable are not stationary at level, this implies the acceptance of null hypothesis. The acceptance of alternate hypothesis enables us to test for stationarity at first difference. From the result, it is evidence that the ADF statistics of the variables are greater than the Mackinnon critical values and the probability coefficient is less than the 0.05 critical values, we therefore conclude that the variables are stationary at first difference, we therefore rejects the null hypothesis. The result in the stationarity test permits us to test for cointegration using the Johansen cointegration test.

Table 3. Johansen Co-Integration Test Results: Maximum Eigen

\begin{tabular}{|c|c|c|c|c|c|}
\hline $\begin{array}{c}\text { Hypothesized } \\
\text { No. of CE(s) }\end{array}$ & Eigen value & Maximum-Eigen & $\begin{array}{c}0.05 \\
\text { Critical Value }\end{array}$ & Prob.** & Decision \\
\hline None* & 0.654936 & 98.24354 & 95.75366 & 0.0036 & Reject $\mathrm{H}_{0}$ \\
\hline At most $1 *$ & 0.547877 & 77.13074 & 69.81889 & 0.0060 & reject $\mathrm{H}_{0}$ \\
\hline At most $2 *$ & 0.230094 & 60.93533 & 47.85613 & 0.0050 & reject $\mathrm{H}_{0}$ \\
\hline At most $3 *$ & 0.189396 & 32.30625 & 29.79707 & 0.0007 & reject $\mathrm{H}_{0}$ \\
\hline At most 4 & 0.150299 & 5.377045 & 15.49471 & 0.7675 & Accept $\mathrm{H}_{0}$ \\
\hline At most 5 & $7.04 \mathrm{E}-05$ & 0.002324 & 3.841466 & 0.9595 & Accept $\mathrm{H}_{0}$ \\
\hline \multicolumn{6}{|c|}{ Trace Statistics } \\
\hline None* & 0.654936 & 75.11280 & 40.07757 & 0.0002 & Reject $\mathrm{H}_{0}$ \\
\hline
\end{tabular}




\begin{tabular}{cccccc}
\hline At most $1 *$ & 0.547877 & 56.19541 & 33.87687 & 0.0090 & reject $\mathrm{H}_{0}$ \\
\hline At most 2* & 0.230094 & 38.629077 & 27.58434 & 0.0467 & reject $\mathrm{H}_{0}$ \\
\hline At most 3 & 0.189396 & 6.929206 & 21.13162 & 0.9566 & Accept $\mathrm{H}_{0}$ \\
\hline At most 4 & 0.150299 & 5.374721 & 14.26460 & 0.6940 & Accept $\mathrm{H}_{0}$ \\
\hline At most 5 & $7.04 \mathrm{E}-05$ & 0.002324 & 3.841466 & 0.9595 & Accept $\mathrm{H}_{0}$ \\
\hline
\end{tabular}

Source: Extracts from E-view

The cointegration test presented in the above table test the presence of long run relationship among the variables. In the cointegration test, we adopt the maximum eigen value coefficient and the trace statistics. The coefficient shows three cointegrating equation from the trace statistics and two from maximum eigen value. We therefore rejects the null hypothesis and concludes that the presence of long run relationship between the dependent and the independent variables

Table 4. Normalized Co-integrating Equation

\begin{tabular}{cccccc}
\hline TCD_TA & PSC_GDP & MOB_GDP & MMD_GDP & M2_GDP & M1_GDP \\
\hline 1.000000 & -9.734320 & -50.27920 & 0.000445 & -6.253786 & 26.56908 \\
\hline & $(2.90327)$ & $(8.56693)$ & $(0.71517)$ & $(5.62676)$ & $(8.17859)$ \\
\hline
\end{tabular}

Source: Extracts from E-view

From the normalized cointegration equation, it is evidence that private sector credit, money outside the bank and broad money supply have negative long run relationship with total customers deposit while money market development and narrow money supply have positive long run relationship with total customers' deposit.

Table 5. Over-Parameterized Result

\begin{tabular}{|c|c|c|c|c|}
\hline VARIABLE & COEFFICIENT & STD ERR. & T-STATISTICS & PROB. \\
\hline $\mathrm{C}$ & -0.388963 & 1.408921 & -0.276072 & 0.7876 \\
\hline D(TCD_TA(-1)) & 0.502663 & 0.256670 & 1.958399 & 0.0760 \\
\hline D(TCD_TA(-2)) & 0.960814 & 0.303538 & 3.165386 & 0.0090 \\
\hline D(TCD_TA(-3)) & 0.851189 & 0.361808 & 2.352600 & 0.0383 \\
\hline D(PSC_GDP(-1)) & -0.585038 & 1.205189 & -0.485432 & 0.6369 \\
\hline D(PSC_GDP(-2)) & 0.735534 & 1.365231 & 0.538761 & 0.6008 \\
\hline D(PSC_GDP(-3)) & -0.308005 & 1.476179 & -0.208650 & 0.8385 \\
\hline D(MOB_GDP(-1)) & -6.912298 & 4.427858 & -1.561093 & 0.1468 \\
\hline D(MOB_GDP(-2)) & 2.531386 & 4.871861 & 0.519593 & 0.6136 \\
\hline D(MOB_GDP(-3)) & 4.805131 & 5.626703 & 0.853987 & 0.4113 \\
\hline D(MMD_GDP(-1)) & 1.152277 & 0.904125 & 1.274467 & 0.2288 \\
\hline D(MMD_GDP(-2)) & 0.564251 & 0.706833 & 0.798281 & 0.4416 \\
\hline D(MMD_GDP(-3)) & -0.370141 & 0.675910 & -0.547619 & 0.5949 \\
\hline D(M2_GDP(-1)) & 0.276736 & 1.894229 & 0.146094 & 0.8865 \\
\hline D(M2_GDP(-2)) & 0.449567 & 2.216291 & 0.202846 & 0.8430 \\
\hline D(M2_GDP(-3)) & 0.455371 & 2.770931 & 0.164338 & 0.8724 \\
\hline D(M1_GDP(-1)) & 2.899752 & 2.855215 & 1.015599 & 0.3316 \\
\hline D(M1_GDP(-2)) & -1.894221 & 3.236970 & -0.585183 & 0.5702 \\
\hline D(M1_GDP(-3)) & -1.608165 & 4.461279 & -0.360472 & 0.7253 \\
\hline $\operatorname{ECM}(-1)$ & -1.355823 & 0.386215 & -3.510540 & 0.0049 \\
\hline R2 & 0.709080 & & & \\
\hline ADJ. R2 & 0.206582 & & & \\
\hline F-STATISTICS & 2.411109 & & & \\
\hline F-PROB & 0.003352 & & & \\
\hline Durbin-Watson & 2.425073 & & & \\
\hline
\end{tabular}

Source: Extracts from E-view print

The over parameterized result on the effect of financial deepening on customers' deposit shows that the independent 
variables $70.9 \%$ and $20.6 \%$ variation on the dependent variable, the F-statistics and F-probability shows that the model is significant while the Durbin Watson statistics shows the presence of serial negative auto correlation. The $\beta$ coefficient of the variables shows that the independent variables at the various lag have positive relationship with the dependent variable except money market development at lag 3, broad money supply at lag 1 and lag 2, money outside the bank at lag 2 and private sector credit at lag 2. The error correction model ECM (-1) is negative which confirm the a-priori expectation, this means that the variables can adjust to equilibrium at the speed of $135 \%$ annually. The presence of serial auto correlation in the above result enables us to test for Parsimonious error correction model.

Table 6. Parsimonious Error Correction Results

\begin{tabular}{ccccc}
\hline VARIABLE & COEFFICIENT & STD ERR. & T-STATISTICS & PROB. \\
\hline C & 0.107424 & 1.648579 & 0.065162 & 0.9488 \\
\hline D(TCD_TA(-1)) & 0.298682 & 0.274872 & 1.086623 & 0.2915 \\
\hline D(PSC_GDP(-2)) & -1.282698 & 1.402075 & -0.914857 & 0.3724 \\
\hline D(PSC_GDP(-3)) & -0.627060 & 1.431850 & -0.437937 & 0.6666 \\
\hline D(MOB_GDP(-1)) & 1.409765 & 3.851281 & 0.366051 & 0.7186 \\
\hline D(MOB_GDP(-2)) & 1.174352 & 3.238169 & 0.362659 & 0.7211 \\
\hline D(MOB_GDP(-3)) & -2.218628 & 3.700021 & -0.599626 & 0.5562 \\
\hline D(MMD_GDP(-1)) & -0.031231 & 0.894682 & -0.034907 & 0.9725 \\
\hline D(M2_GDP(-1)) & 0.087538 & 1.293760 & 0.067662 & 0.9468 \\
\hline D(M2_GDP(-2)) & 1.203299 & 1.513621 & 0.794980 & 0.4370 \\
\hline D(M2_GDP(-3)) & 1.117702 & 1.767288 & 0.632439 & 0.5351 \\
\hline D(M1_GDP(-1)) & -0.579035 & 2.676208 & -0.216364 & 0.8311 \\
\hline ECM(-1) & -0.567608 & 0.257732 & -2.202320 & 0.0409 \\
\hline C & 0.107424 & 1.648579 & 0.065162 & 0.9488 \\
\hline R2 & 0.322084 & & \\
\hline ADJ. R2 & 0.129860 & & \\
\hline F-STATISTICS & 0.712663 & & \\
\hline F-PROB. & 0.721768 & & \\
\hline Durbin-Watson & 2.204684 & & \\
\hline
\end{tabular}

Source: Extracts from E-view print out and Author's computation

The Parsimonious error correction model on the effect of financial deepening shows that private sector credit have negative effect at Lag 1 and Lag 2, money outside the bank have positive effect at Lag 1 and Lag 2 but negative at Lag 3, money market development have negative impact at Lag 1 while Broad money supply have positive effect at Lag 1 and Lag 2 but negative effect at Lag 3. The model summary prove that the independence variable $32.2 \%$ and $12.9 \%$, the error correction model shows that the variables can adjust to equilibrium at the speed of $57.9 \%$ annually. The T- statistics and the probability shows that broad money supply is significant at Lag 2 while other variables are statistically not significant.

Table 7. Pair Wise Causality Test

\begin{tabular}{cccc}
\hline PSC_GDP does not Granger Cause TCD_TA & 33 & 0.80343 & 0.4578 \\
\hline TCD_TA does not Granger Cause PSC_GDP & & 2.39933 & 0.1092 \\
\hline MOB_GDP does not Granger Cause TCD_TA & 33 & 0.06015 & 0.9417 \\
\hline TCD_TA does not Granger Cause MOB_GDP & & 0.21594 & 0.8071 \\
\hline MMD_GDP does not Granger Cause TCD_TA & 33 & 0.04973 & 0.9516 \\
\hline TCD_TA does not Granger Cause MMD_GDP & & 0.88795 & 0.4228 \\
\hline M2_GDP does not Granger Cause TCD_TA & 33 & 0.40649 & 0.6699 \\
\hline TCD_TA does not Granger Cause M2_GDP & & 2.44138 & 0.1054 \\
\hline M1_GDP does not Granger Cause TCD_TA & 33 & 0.24104 & 0.7874 \\
\hline TCD_TA does not Granger Cause M1_GDP & & 2.74219 & 0.0817 \\
\hline \hline
\end{tabular}

Source: Extracts from E-view 
In the granger causality T-test, the result shows that there is no causal relationship that exists between the dependent and the independent variables or the independent to the dependent variable. We therefore accept the null hypothesis, this contrary to the expectation of the result.

\section{Discussions of Findings}

Financial sector development is a prerequisite for achieving desired monetary and macroeconomic goals. The study found that narrow money supply have negative but insignificant effect on total customer deposit of commercial banks such that a unit increase on the variable will lead to $3.7 \%$ decrease on the total customer deposit of commercial banks This finding is contrary to the expectation of the results and contradicts the objective of financial sector reforms. Narrow money supply which includes currency in circulation and demand deposit is expected to have a positive impact on the liquidity of commercial banks. The negative impact of narrow money supply is contrary to the findings of (Hlatshwayo et al., 2013 and Vazquez and Federico, 2012) on the impact of financial market development and the liquidity position of commercial banks in Pakistan. The negative impact of narrow money supply on the liquidity position of commercial banks in Nigeria can be traced to the fact that demand deposit is prone to frequent withdrawal. It could also be traced to the fact that the significant proportion of the currency in circulation is outside the banking system, this implies that increase in narrow money supply will significantly reduce the liquidity of commercial banks in Nigeria.

The impact of broad money supply is positive and insignificantly related to total customers deposit such that a unit increase will lead to $3.6 \%$, the positive effect of broad money supply on customers deposit confirm the a-priori expectation of the result and validates the monetary policy objective and the regulatory functions of the monetary authorities which is to achieve banking system stability while the positive effect confirm the findings of Bundi (2013) on the effect of financial sector liberalization on the liquidity of commercial banks and Odhiambo (2008) on the effect of interest rate on liquidity of commercial banks, the negative impact confirm the findings of Fallah (2012) on the effect of nonperforming loans on liquidity of commercial banks. Findings reveal that money market development has negative relationship with customer deposit of commercial banks. This finding is contrary to the expectation of the results and various policies formulated by the regulatory authorities to deepen the operational efficiency of the Nigerian money market such as the increase in the money market instruments and the reforms in the money market institutions such as the banking sector reforms. Toby (2006) noted that the banking sector consolidation was aimed at repositioning Nigerian commercial banks to become a player in the international financial market and not a spectator. The negative effect of the variables could be traced to poor implementation of policies and conflict of monetary policy with the liquidity of objectives of commercial banks such as the withdrawal of all public funds from the banking sector in 1990s and the introduction of the single treasury account system the policy that threatened the liquidity of Nigerian commercial banks and motivates the industry into the international financial market in source for liquidity. The study found that money outside the bank have positive and significant effect on customer deposit such that a unit increase on the variable will lead $29.9 \%$ on total customers' deposit, this finding is contrary to the expectation of the result as money outside the bank is expected to have a negative impact on the liquidity position of commercial banks. It is contrary to the opinion of former central bank governor Prof Charles Soludo that money outside the bank constitutes a lot of nonsense to the financial market and the economy at large. The finding of this study validates the existence of informal financial institutions Esusu and other methods of informal savings. The positive impact could be traced to the lost of public confidence in the banking sector in the 1980s and 1990s as a result of frequent banking sector distress. It could also be traced to information asymmetric between the depositors and the lenders of fund in the financial market. The study found that private sector credit has positive but insignificant impact on total liquid assets of commercial banks and total customers' deposit. This finding confirms the a-priori expectation of the results and justifies the positive findings above.

6. Conclusion

This study established that the components of financial deepening play key roles in determining the customers' deposits of commercial banks in Nigeria and were found to be statistically significant. The study also established the relevance of specified components of financial deepening on customer's deposit of quoted commercial banks. It was discovered that the contribution to financial deepening was positive and significant customers deposit liabilities. Result of the analysis and finding thereof has provided some interesting insights that will enhance clearer understanding of financial deepening and deposit mobilization of commercial banks in Nigeria. This study concludes financial deepening significant effect on the deposit mobilization.

\section{Recommendation}

From the findings of the study, there is need to sustain a higher level of financial deepening in Nigeria. Incidences of poor liquidity should be minimized and private sector credits channeled to the real sector of the economy should be enhanced through monetary and macroeconomic policies. Moreover, policy oriented measures should take into consideration the positive causality between money outside the banks and liquidity of commercial banks in Nigeria. 
Bank managers should identify and monitor key business drivers such as loan and deposit margins as these are the outcome of financial sector development to enhance effective liquidity policy of the banking industry.

Bank officials should be trained in the areas of liquidity management and liquidity changing conditions and should be forward looking, and focus on operational efficiency of the banking industry to leverage the negative impact of narrow money supply and broad money supply of commercial banks in Nigeria. High quality liquidity assets buffer sufficient to hedge sudden liquidity outflows should be maintained and there should be regular review of prudential guidelines for efficiency to hedge against the negative impact of financial deepening measures on liquidity of Nigeria commercial banks. The positive impact of money outside the bank is contrary to the expectation of the study, therefore there is need for the monetary authorities and the financial market regulators to formulate policies that will deepen the operational efficiency of the Nigeria financial market for effective liquidity management of commercial banks.

References

Abubakar, A., \& Gani, I. M. (2013). Impact of banking sector development on economic growth: Another look at the evidence from Nigeria. Journal of Business Management \& Social Sciences Research (JBM \& SSR),2(4), 47-57

Abu-Zeinab, A. (2013). Patterns of bank credit allocation and economic growth: The case of Denmark 1736 -2012. Lund Papers in Economic History(General Issues 131), 1-35.

Akabom-Ita, A. (2012). Impact Analysis of Interest Rate on the Net Assets of Multinational Businesses in Nigeria. Research Journal of Finance and Accounting 3 (7), 146-167.

Akpansung, A. O. \& Babalola, S. J. (2012). Banking Sector Credit and Economic Growth in Nigeria: An Empirical Investigation. CBN Journal of Applied Statistics, 2 (2):51 -62.

Avinash, R., \& Mitchell-Ryan, T. (2009). An assessment of the impact of the sectoral distribution of commercial bank credit on economic growth and development in Trinidad and Tobago. CBB Working Paper, 2010.Trinidad and Tobago: Central Bank of Trinidad and Tobago.

Ayadi, R., Arbak, E. S., \& De Groen, W. P. (2013). Financial development, bank efficiency and economic growth across the Mediterranean. MEDPRO Technical Report No. 30.

Bhusal, B. P. (2012). Impact of financial policy reforms on financial development and economic growth in Nepal. International Journal of Business and Social Sciences, 3(14), 33-45.

Bossone, B., \& Lee, J.-K. (2004). In Finance, Size Matters: The "Systematic Scale Economies" Hypothesis. IMF Staff Papers, 51(1), 19-46.

Capannelli, G.J. (2009). Developing Indicators for Regional Economic Integration and Cooepration. Asian Development Bank, No. 33.

Chortareas, G. E., Garza-Garcia, J. G., \& Girardone, C. (2011). Financial deepening and bank productivity in Latin America. The European Journal of Finance, 17(9-10), 811-827.

Christian, L.N. (2013). Financial deepening dynamics and implication for financial policy Coordination in a Monetary Union: The Case of WAEMU. African Economic Conference 2013 Johannesburg.

Diamond, D.W. (1983). Bank Runs, Deposit Insurance and Liquidity. Journal of Political Economy, University of Chicago Press.

Dickey, D.A., Fuller, W.A. (1981). Distribution of the Estimators for Autoregressive Time series with a Unit Root. Journal of the American Statistical Association, 74(366), 427-431.

Fadare, S. O. (2010). Recent banking sector reforms and economic growth in Nigeria. Middle Eastern Finance and Economics, 8, 146-160.

Fafchamps, M., \& Schundeln, M. (2011). Local financial development and firm performance: Evidence from Morocco.

Galbis, V. (1997). Financial Intermediation and Economic Growth in Less Developed Countries: A Theoretical Approach. Journal of Development Studies, 13, 58-72

Gujarati, N.D. (2007). Basic Econometrics. New York: McGraw Hill, Inc, 4th Edition.

Hammilton, O.I. and Godwin (2013). Does financial deepening follow supply leading or demand following hypothesis? A Critical Look at the Nigerian Evidence. Journal of Science and Technology, 5, 10-15.

Ikenna, O. D. (2012). Financial Deregulation in Bounding to Credit Mobilisation in Nigeria: A Case for the Real Sectors and SMEs. IOSR Journal of Humanities and Social Science, 5(5), 40-59.

Imoughele, Ehikioya, L., Ismaila, \& Mohammed. (2013). Commercial bank credit accessibility and sectoral output performance in a deregulated financial market economy: Empirical evidence from Nigeria. Journal of Finance and Bank Management, 1(2), 36-59.

Jhingan, M. L. (2004). Monetary Economics (6th ed.). New Delhi, India: Vrinda Publications (P) Ltd. 
King, R. G. \& Levine, R. (1993). Finance, Entrepreneurship, and Growth: Theory and Evidence. Journal of Monetary Economics, 32, 513-542.

Levine, R., \& Loayza, N. (1999). Financial Intermediation and Growth - Causality and Causes. World Bank Policies Research Working Paper No. 2059-1999.

Lucky, A. L., \& Uzah, C. K., (2017). Monetary Policy Transmission Mechanisms and Domestic Real Investment in Nigeria: A Time Series Study 1981-2015. IIARD International Journal of Economic and Financial Management, 2 (2), 29 - 59.

Mathiesun, D.J. (1980). Financial Reform and Stabilization Policy in a Developing Economy. Journal of Development Economics , 7, 359-395.

McKmnon, R.I. (1973). Money and Capital in Economic Development. The Brookings Institution, Washington DC.

Nazmi, N. (2005). Deregulation, financial deepening and economic growth: The case of Latin America. The Quarterly Review of Economics and Finance, 45, 447-459.

Ndebbio, J.E.U. (2004) .Financial Deepening, Economic Growth and Development: Evidence from Selected SSA Countries. African Economic and Research Consortium, RP142.

Newman, E. (2012). Impact of Interest Rate Policy and Performance of Deposit Money Banks in Nigerian Global Journal of Management and Business Research; 12 (21), 16-34.

Ngerebo-a, T.A., \& Lucky, A. L., (2016). Interest Rates and Deposit Money Bank's Profitability: Evidence from Nigeria (1980 - 2014). International Journal of Empirical Finance, 5 (1), 22 - 35.

Nwanyanwu, O. J. (2012). Analysis of banks' credit on Nigeria's economic growth (1992 - 2008). Jos Journal of Economics, 4(1), 43 - 58.

Obilor, S. I. (2013). The impact of commercial banks' credit to agriculture on agricultural development in Nigeria: An econometric analysis. International Journal of Business, Humanities and Technology, 3(1), 85-95.

Ochanda, M. M. (2014). Effect of financial deepening on growth of small and medium-sized enterprises in Kenya: A case of Nairobi County. International Journal of Social Sciences and Entrepreneurship, 1(11), 191-208.

Odhiambo, N. M. (2009a). Interest Rate Reforms, Financial Deepening and Economic Growth in Kenya: An Empirical Investigation. The Journal of Developing Areas, 43(1), 295-313.

Odhiambo, N. M. (2009b). Financial Deepening and Poverty Reduction in Zambia: an Empirical Investigation. International Journal of Social Economics, 37(1), 41-53.

Omankhanlen, A. E. (2012). The financial sector reforms and their effect on the Nigerian economy. Economy Transdisciplinarity Cognition, 15(2), 45-57.

Onyemachi, C. (2012). An empirical analysis of financial deepening and economic growth (1986-2010). Ahmadu Bello University, Economics, Zaria.

Osinsanwo, B.G. (2013). The macroeconomic effect of financial development on economic growth in Nigeria: A Long Run Analysis, 1970-2011. Journal of African Macroeconomic Review, 4, 227-245.

Shaw, E.S. (1973). Financial Deepening in Economic Development. New York: Oxford University Press.

Sindani, M. (2013). The impact of financial sector deepening on economic growth in Kenya. International Journal of Social Sciences and Project Planning Management, 1(1), 41-64.

Toby, A. J., \& Peterside, D. B. (2014). Analysis of the Role of Banks in Financing the Agriculture and Manufacturing Sectors in Nigeria. IMPACT: International Journal of Research in Business Management (IMPACT: IJRBM), 2(2), 9-22.

Tomola, M. O., Adebisi, T. E., \& Olawale, F. K. (2010). Bank lending, economic growth and the performance of the manufacturing sector in Nigeria. European Scientific Journal, 8(3), 19-36.

Were, M., Nzomoi, J., \& Rutto, N. (2012). Assessing the impact of private sector credit on economic performance: Evidence from sectoral panel data for Kenya. International Journal of Economics and Finance, 4(3), 182 190.

\section{Copyrights}

Copyright for this article is retained by the author(s), with first publication rights granted to the journal.

This is an open-access article distributed under the terms and conditions of the Creative Commons Attribution license (http://creativecommons.org/licenses/by/4.0/). 